Working Paper n. 01 - 2008

\title{
BANKRUPTCY SYSTEMS AND ECONOMIC PERFORMANCE ACROSS CONTRIES: SOME EMPIRICAL EVIDENCE
}

\author{
Marianna Succurro \\ Dipartimento di Economia e Statistica \\ Università della Calabria \\ Ponte Pietro Bucci, Cubo 1/C \\ Tel.: +390984 492443 \\ Fax: +390984 492421 \\ e-mail:m.succurro@unical.it
}

Dicembre 2008

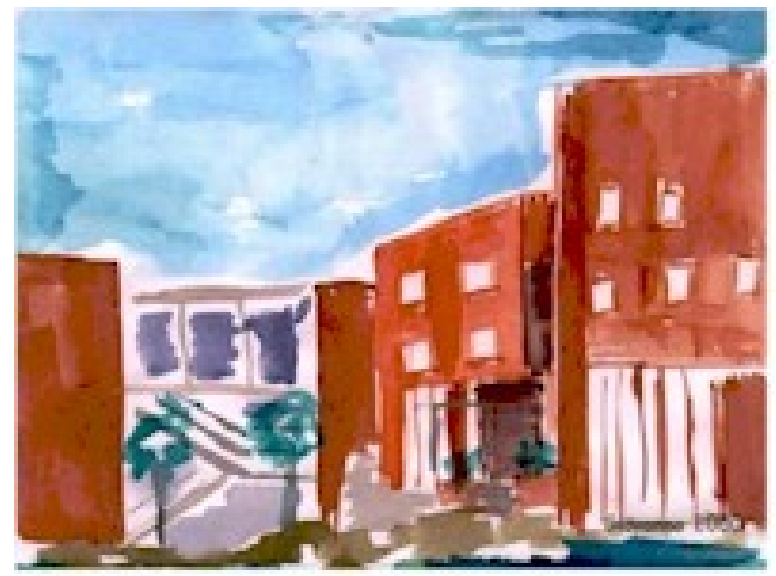




\title{
BANKRUPTCY SYSTEMS AND ECONOMIC PERFORMANCE ACROSS COUNTRIES: SOME EMPIRICAL EVIDENCE
}

\author{
Marianna Succurro \\ Department of Economics and Statistics \\ University of Calabria \\ 87036 Rende (CS), Italy \\ email:m.succurro@unical.it \\ Tel. +390984492443
}

"Neither a borrower nor a lender be" (W. Shakespeare, in Hamlet)

\begin{abstract}
This paper examines the relationship between the insolvency systems and the investment share of GDP across countries. The objective is to find out the relationship between bankruptcy procedures and economic performances around the world.

Empirical evidence suggests that: 1) the investment share of GDP is higher in those countries characterized by highly efficient bankruptcy system; the more efficient the insolvency procedures in terms of time, cost and recovery rate, the more readily available debt is and the higher the Investment/GDP ratio is; 2) the investment share of gross domestic product is positively associated with the degree of sophistication of the Bankruptcy Law, at least below a certain level of legal production; 3) data suggest some complementary effect between Bankruptcy Law and Enforcement for rich countries, while the interaction term indicates some substitution effect when poor countries are considered. Some policy implications conclude the work.
\end{abstract}

Keywords: Bankruptcy Law - Enforcement - Investments - Economic Performance

JEL Classification: G33; K40; O40.

\section{Introduction}

Many economists stress the importance of the institutions and the legal system for understanding economic development. Several studies focus attention on the link between the evolution of legal and financial systems and economic development (La Porta et al. 1998; La Porta et al. 1997; Levine 1998; Rajan and Zingales 1998; King and Levine 1993) but they “... do not control for crosscountry differences in bankruptcy procedures” (Levine 1998, pag. 600). Other researches investigate bankruptcy procedures around the world (Djankov et al. 2007; Claessens and Klapper 2005) but they do not explicitly study the connection between bankruptcy environment and economic performance. The objective of the paper is to fill this gap in the literature.

Given the current international financial crisis, caused by the subprime mortgage crisis, many households and firms are likely to go under ${ }^{1}$. Also the mortgage financing companies and banks,

\footnotetext{
${ }^{1}$ US household debt as percentage of income rose to $130 \%$ during 2007 , versus $100 \%$ earlier in the decade. Americans spent $\$ 800$ billion per year more than they earned. Household debt grew from $\$ 680$ billion in 1974 to $\$ 14$ trillion in 2008, with the total doubling since 2001(Newsweek.com, retrevied on 24 Oct 2008).
} 
which usually play the role of guaranteed creditors in a standard insolvency procedure, are likely to go under without the state aid. The declared bankruptcy of Lehman Brothers, the $4^{\text {th }}$ US investment bank and one of the biggest US financial institution, is a well known case.

Now it is a perfect time to reconsider an old question“...how to handle such failures: let them sink, or give them a chance to swim?” (The Economist 2002). America's bankruptcy code, in particular its Chapter 11 protection for firms from their creditors, is particularly friendly to troubled borrowers, allowing them to borrow more money and giving them time to work out their problems. Some other countries quickly close down a bankrupt firm, and try to repay its debts by selling off any assets it has.

This research adds to the ongoing discussion on bankruptcy systems and their efficiency. Two clarifications, however, are required. First, even if the household over-indebtedness and consumer bankruptcy is a relevant field of discussion given the current financial crisis, the paper focuses on firms' bankruptcy. European Commission has only recently suggested a common definition of personal over-indebtedness ${ }^{2}$ (European Commission 2008). Moreover, few countries around the world explicitly regulate personal bankruptcy, while firms' bankruptcy law is available in the majority of countries, although with different degrees of sophistication. Second, the research considers ex-post regulation efficiency (how to solve insolvency) and not ex-ante regulation (how to avoid insolvency).

The aim of the paper is to examine whether and to what extent cross-country differences in the Bankruptcy law and its efficiency explain cross-country differences in the level of investment share of GDP. Answering this question has important policy implications, given the current legislative and regulatory responses to lending practices and bankruptcy protection. Both the bankruptcy law and its enforcement may influence ex-ante risk-taking incentives and total amount of investment. Bankruptcy regulation, however, is not an easy task because of significant counterbalancing factors. On the one side, good bankruptcy laws make it easier for firms to get credit and invest because they strengthen creditors' power and reassure them that they will not lose their money if the debtor becomes insolvent. On the other side, if bankrupts are punished too severely, would-be entrepreneurs may be discouraged from taking the financial risks needed to make the most of their ideas. As it is known, how bankrupts are treated may significantly affect economic growth: “... the availability of debt, and the willingness to take it on, is a crucial ingredient of economic growth, because it allow individuals, firms and governments to make investments they would not otherwise be able to afford" (www.economist.com/research/Economics, retrieved on 22 Oct 2007).

The paper finds that both the degree of sophistication of the Bankruptcy Law and the efficiency of the insolvency proceedings are positively associated with the investment share of gross domestic product. In rich countries, however, the investment share of GDP would be influenced by the expected enforcement of bankruptcy procedures more than the degree of sophistication of the Bankruptcy Law. Legal production is sufficiently high and overlapping laws have often decelerated the civil justice and increased the costs of the insolvency proceedings. When poor countries' investments are considered, bankruptcy law enters significantly with the expected positive sign. The result could be partially explained by the fact that poor countries usually have very simple debt enforcement proceedings. When bankrupts are expected to be punished too quickly and severely, entrepreneurs may be discouraged from taking the financial risks needed to make their investments, as well as letting off defaulting debtors too readily may discourage potential creditors because of moral hazard. Therefore, a certain degree of sophistication of the Bankruptcy Law is desirable at the least to guarantee creditors and make investments possible.

\footnotetext{
2 "over-indebtedness means, but is not limited to, the situation where the debt burden of an individual or a family manifestly and/or on a long-term basis exceeds the payment capacity” (Group of Specialists for Legal Solutions to Debt Problems, Cj-SDebt).
} 
Furthermore, the estimation results would suggest some complementary effect between the degree of sophistication of the Bankruptcy Law and the efficiency of the insolvency procedures in rich countries, while the interaction term indicates some substitution effect in poor countries, suggesting that countries characterized by weak bankruptcy law have answered by rigorously enforcing insolvency procedures.

The paper is organized as follows. Section 1 presents a brief literature review. Section 2 summarizes the main insolvency procedures and the recent bankruptcy reforms around the world. Section 3 describes the methodology and the data. Section 4 presents empirical evidence. Some concluding remarks follow.

\section{Literature Review}

Several theoretical and empirical studies on the effects of insolvency procedures and their efficiency have emerged in recent law and economics literature.

Theoretical studies concern the financial structure of firms and incomplete debt contracts (Tirole 2006; Hart et al. 1997; Zwiebel 1996; Hart 1995; Aghion and Bolton 1992; Bolton and Scharfstein 1990; Hart and Moore 1989). Hart (1995) develops a theoretical model of debt finance that allows to identify necessary conditions for projects finance. Tirole (2006) emphasizes the governance function of debt as control mechanism for managers' opportunism. The extreme case of bankruptcy could determine a loss of reputation for managers, frequently followed by a stigma and social disapproval. Moreover, the decision to keep liquidity outside the firm can be read as a strategy to prevent managers from wasting financial resources in investments which are not profitable for the firm. Hart et al. (1997) describe a new efficient insolvency procedure based on two types of auctions, an internal auction and a public auction, which allows low discretion to courts, managers, creditors and shareholders. Moreover, this insolvency procedure can be adopted also in those countries where the financial markets do not work well, such as developing countries transition economies.

The case of multiple investors is explicitly considered by Dewatripont and Tirole (1994), Berglof and von Thadden (1994).

The empirical literature includes two types of studies. In the first group, bankruptcy is analysed at a firm-level in specific settings within a specific country (Couwenberg and de Jong 2008; Bris et al. 2006; Armour et al. 2006; Baird et al. 2005; Davidenko and Franks 2005; Franks and Sussman 2005; Lopucki and Doherty 2004; Citron et al. 2003; Ferris and Lawless 2000; Lubben 2000; Thorburn 2000; Ravid and Sundgren 1998; Sundgren 1998; Betker 1997; Tashijan et al. 1996; Franks et al. 1996; Betker 1995; Franks and Torous 1994; Weiss 1990).

In the second group of empirical studies, the legal system is analysed across countries. Legal variables are related to other country characteristics in order to measure the macro-economic implications of legal systems.

One fundamental research is that of La Porta et al. (1998) that examines legal rules covering protection of corporate shareholders and creditors, the origin of these rules, the quality of their enforcement and ownership concentration in 49 countries. The results show that laws, as well as law enforcement, differ markedly around the world depending on the legal origin of a country ${ }^{3}$. They also find that concentration of ownership of shares in the largest public companies is negatively related to investor protection, consistently with the hypothesis that small, diversified shareholders are unlike to be important in countries that fail to protect these rights.

\footnotetext{
${ }^{3}$ In particular, countries whose legal rules originate in the common-law tradition tend to protect investors considerably more than the countries whose laws originate in the civil-law (especially the French-civil-law) tradition. Also law enforcement differs a great deal around the world. German-civil-law and Scandinavian countries have the best quality of law enforcement, while law enforcement is strong in common-law countries (La Porta et al. 1998).
} 
Other studies analyse the link between finance and growth ${ }^{4}$. La Porta et al. (1997) show that countries with poor investor protections have significantly smaller debt and equity market. King and Levine (1993), Levine (1998) and Levine and Zervos (1998) find that financial development promotes economic growth. Rajan and Zingales (1998) find that countries with better developed financial systems show superior growth in capital-intensive sectors that rely particularly heavily on external finance.

All these studies describe a link from the legal system, more specifically creditors' rights, to economic development. Recent financial crises have highlighted the importance of insolvency systems to resolve corporate sector financial distress. Creditor rights would affect not only the efficiency of ex-post resolution of distressed corporation, but also the ex-ante risk-taking incentives and an economy's degree of entrepreneurship more generally. Claessens and Klapper (2005) document how often bankruptcy is used for a panel of 35 countries. They find that bankruptcies are higher in Anglo-Saxon countries and in market-oriented financial systems more than bank-oriented economies. Moreover, greater judicial efficiency is associated with more use of bankruptcy, but the combination of stronger creditor rights with greater judicial efficiency leads to less use. Djankov et al. (2007) focus attention on debt enforcement around the world. They construct a measure of the efficiency of debt enforcement in each country and find that it is strongly correlated with per capita income, legal origin and with measures of the quality of contract enforcement and public regulation obtained in other studies. Looking at worldwide averages, all procedures are extremely time consuming, costly and inefficient, but there is some evidence that richer countries have a comparative advantage at more complex procedures. In the rich countries, the most efficient procedure is reorganization, in the lower middle income countries the best procedure is foreclosure since the attempts to rehabilitate the firm nearly always fail. Recent empirical evidence would suggest that different debt enforcement institutions might be appropriate for countries at different income levels (Ayotte and Yun 2007; Gennaioli and Rossi 2006; Djankov et al. 2003). For this reason, even if data show that the insolvency law and efficiency of the bankruptcy proceedings vary significantly also across rich countries (think about the Italian civil justice inefficiency), most of the following analysis distinguishes between rich and poor countries.

This research contributes to the second group of empirical studies by giving some evidence on bankruptcy systems and economic performances across 91 countries over the 1992-2006 period.

\section{Bankruptcy procedures around the world}

Insolvency procedures and judicial efficiency vary significantly across countries. Some countries have complex insolvency systems while others have simple liquidation procedure. However, the usual distinction concerns pro-debtor and pro-creditor systems.

The US Bankruptcy Code represents the pro-debtor system above all others. In America, bankruptcy has come to mean a second chance for bust businesses. The famous "Chapter 11" law, the reorganization provision in the US Bankruptcy Code, aims at giving a company time to get back on its feet, by shielding it from debt payments and prodding banks to negotiate with their debtor. It even allows an insolvent company to receive fresh finance after it goes bust.

On the other side of the Atlantic, when companies stumbled, almost as much effort was spent in fingering the guilty as in trying to salvage a viable business. British, Italian and French laws, for example, established criminal penalties and personal liability for a failing company's manager. Moreover, bankers had the power, at the first sign of trouble, to push a company into the arms of the receivers. Some reforms have been adopted in recent years, however.

\footnotetext{
${ }^{4}$ For a critical survey see Trew (2006).
} 
Several European countries, on the basis of Chapter 11 US Bankruptcy Code, changed their bankruptcy law due to a lack of the reorganization power of their systems. The liquidation-based origins of these European laws were considered out of date and were deemed to lead to overliquidation (Couwenberg and de Jong 2008). Belgium changed its rules in 1998, France in 1994, Finland in 1993, Germany in 1994 (Couwenberg 2001), the UK in 2002, Italy in 2005/2006.

Other European and Non-European countries adopted to various degrees bankruptcy reforms (table1). A new bankruptcy law drafted in 2004 in Czech Republic may drastically improve the efficiency of financial distress resolution. Brazil introduced a reorganization procedure in 2004 that helps viable enterprises stay alive and gives secured creditors more influence over the process. Serbia also introduced reforms in 2004, setting strict time limits and strengthening accountability standards for bankruptcy administrators. In 2005/06 fourteen countries ${ }^{5}$ adopted bankruptcy reforms (forty since 2003); among these, only Peru and Uzbekistan adopted negative reform. Burundi and Micronesia both enacted their first bankruptcy law. France, Italy, Korea and Slovakia adopted reforms that allow preinsolvency proceedings and make reorganization more attractive; Chile, Latvia, Serbia and Slovakia adopted reforms that improve supervision of administrators. Also Puerto Rico and United States shortened time limits for bankruptcy procedures (World Bank, Doing Business Report 2007)

Five countries in Eastern Europe and Central Asia (Georgia, Armenia, Hungary, Croatia, Uzbekistan) joined China as top reformers in bankruptcy in 2006/07 (table 1). Also Italy, Denmark and Portugal improved their bankruptcy systems in 2007 (World Bank, Doing Business Report 2008).

Table 1 Bankruptcy Reforms, 2005-2007

\begin{tabular}{|c|c|}
\hline Positive Reforms & Countries \\
\hline Introduced first bankruptcy law & Burundi, Micronesia \\
\hline $\begin{array}{l}\text { Allowed preinsolvency proceedings and made } \\
\text { reorganization more attractive }\end{array}$ & France, Italy, Korea, Slovakia \\
\hline $\begin{array}{l}\text { Strengthened creditors' powers and improved } \\
\text { supervision of administrators }\end{array}$ & France, Korea, Romania, Slovakia \\
\hline Granted priority to secured creditors & China, Hungary, Uzbekistan \\
\hline $\begin{array}{l}\text { Introduced or shortened time limits on bankruptcy } \\
\text { procedures }\end{array}$ & $\begin{array}{l}\text { Armenia, Georgia, Puerto Rico, } \\
\text { Slovakia, United States }\end{array}$ \\
\hline Established reorganization procedure & China, Georgia \\
\hline Set up one-stop shop for voluntary liquidation & Portugal, Uzbekistan \\
\hline Introduced professional requirements for trustees & Croatia, Georgia \\
\hline Strengthened trustees' role & Denmark, Italy \\
\hline Allowed sale at private auction & Mauritius \\
\hline Negative Reforms & Countries \\
\hline $\begin{array}{l}\text { No longer possible to amend a reorganization plan } \\
\text { once it has been approved }\end{array}$ & Peru, Uzbekistan \\
\hline $\begin{array}{l}\text { Amended its Insolvency Act to give wage claims } \\
\text { preference over the claims of secured creditors }\end{array}$ & Botswana \\
\hline $\begin{array}{l}\text { Stripped bankruptcy judges of jurisdiction over labor } \\
\text { lawsuits and exempted such claims from the } \\
\text { automatic stay applicable to claims }\end{array}$ & Argentina \\
\hline
\end{tabular}

Source: Doing Business database

\footnotetext{
${ }^{5}$ The countries are Burundi, Chile, France, Italy, Korea, Latvia, Micronesia, Peru, Puerto Rico, Romania, Serbia, Slovakia, United States, Uzbekistan (World Bank Doing Business Report 2007).
} 
Apart from specific differences in bankruptcy provisions across countries, the legal procedures for resolving a firm's insolvency can generally lead to two different outcomes: the firm continuing operation as a going concern or to its piecemeal sale (Djankov et al. 2007; Couwenberg 2001). Three types of procedure are essentially adopted around the world to obtain such outcomes.

Foreclosure is a relatively simple debt enforcement procedure aimed at recovering money owed to secured creditors. Foreclosure does not protect unsecured creditors, who must rely on separate insolvency proceedings to recover the amounts owed them ${ }^{6}$.

Liquidation is the procedure of winding up a company under court supervision. Firms can either sell their assets piecemeal or, via a going concern asset sale, sell assets as a complex in which the asset specific synergies may be retained.

Reorganization is a court-supervised procedure aimed at rehabilitating companies in financial distress. Firms are given the opportunity to renegotiate with creditors in order to adjust their liabilities. This procedure protects the company while it attempts to rehabilitate itself; in fact, once reorganization begins, creditors generally may not enforce their claims against the company. If the process yields an acceptable agreement, then a court has the power to confirm that plan that can be forced upon dissenting creditors; those firms that fail to get an accepted plan are in most instances transferred to the liquidation procedure. If the reorganization plans are not successful, the firms reenter the bankruptcy procedure ${ }^{7}$. The current management of the insolvent firm may or may not retain control of the company during reorganization.

In the following analysis, the described insolvency procedures are used to measure the degree of sophistication of the Bankruptcy Law adopted in each country.

\section{Methodology and data}

The empirical analysis investigates the legal determinants of investment share of GDP focusing attention, in particular, to bankruptcy proceedings across 91 countries over the 1992-2006 period ${ }^{8}$. The goal of the research is to verify whether, and to what extent, differences in the Bankruptcy law and efficiency explain differences in investment percentage of GDP. The regression takes the form:

$$
\frac{I N V}{G D P}{ }_{i t}=\beta_{0}+\beta_{1} B A N K R_{t t}+\beta_{2} E N F_{i t}+\beta_{3} R U L E_{i t}+\beta_{4} I N T_{i t}+\beta_{5} S A V_{i t}+\beta_{6} F I N_{i t}+\beta_{7} R I S K_{i t}+\gamma_{t}+u_{i}+\varepsilon_{i t}
$$

$t=1992, \ldots, 2006 \quad i=1, \ldots, 91$ countries

\footnotetext{
${ }^{6}$ Note that in some countries foreclosure is governed by laws separate from bankruptcy law (Djankov et al. 2006). Furthermore, within the United States and many other countries, several types of foreclosure exist. Foreclosure by judicial sale, more commonly known as judicial foreclosure, involves the sale of the mortgaged property, subject to auction, under the supervision of a court. Foreclosure by power of sale, commonly referred to as statutory or nonjudicial foreclosure, involves the sale of the property by the mortgage holder without court supervision. With this type of foreclosure, if the debtor fails to cure the default, or use other lawful means (such as filing for bankruptcy which provides a temporary automatic stay to the foreclosure proceeding) to stop the sale, the mortgagee or its representative will conduct a public auction. The highest bidder at the auction becomes the owner of the immovable property free and clear of any interest of the former owner but the property may be encumbered by any liens superior to the mortgage being foreclosed (e.g. a senior mortgage, unpaid property taxes etc). Other types of foreclosure are considered minor because of their limited availability. Under strict foreclosure, the noteholder claims the title and possession of the property back in full satisfaction of a debt, usually on contract. More specifically, suit is brought by the mortgagee and, if successful, a court orders the defaulted mortgagor to pay the mortgage within a specified period of time. Should the mortgagor fail to do so, the mortgage holder gains the title to the property with no obligation to sell it. This type of foreclosure is generally available only when the value of the property is less than the debt ("under water"). Historically, strict foreclosure was the original method of foreclosure. The analysis of the different types of foreclosure, however, is out of the scope of this study.

${ }^{7}$ For an overview of survival routes in Sweden, France, Germany, United Kingdom and United States see Couwenberg (2001).

${ }^{8}$ The list of countries, chosen on the basis of the availability of data, is reported in table A1 in the Appendix.
} 
The dependent variable equals total amount of investments of a country divided by GDP.

$B A N K R_{i}$ measures the degree of sophistication of the bankruptcy law in country $i$. It equals 0 if the country has no practice, 1 if foreclosure is the only debt enforcement proceeding available in the country, 2 if liquidation is also available in the country, 3 if also reorganization procedures are adopted in the country.

$E N F_{i}$ measures the efficiency of the bankruptcy system and it is expressed as an international rank (lower rankings mean higher efficiency). It is a composite index taking into account proceedings time, actual costs and recovery rates of the bankruptcy proceedings (World Bank, Doing Business Report 2008). Time is recorded in calendar years and captures the estimated duration required to complete a bankruptcy. The cost of the bankruptcy proceedings is recorded as a percentage of the estate's value ${ }^{9}$. The recovery rate is recorded as cents on the dollar recovered by claimants through the bankruptcy proceedings ${ }^{10}$.

$R U L E_{i}$ measures the rule of law for country $i$ and is taken from the Worldwide Governance Indicators (WGI) project of the World Bank. It is an index for the "integrity" of the legal environment.

$I N T_{i}$ is the interest rate of banks (lending rate, average annual percentage) for country $i$ reported by the IMF International Financial Statistics; the considered variable is expressed in real terms (base year 2000).

$S A V_{i}$ indicates Gross National Savings as percentage of GDP for country $i$ and is extracted from the World Bank Development Report ${ }^{11}$.

FIN $_{i}$ measures the financial market development of country $i$. It is given by the domestic credit provided by banking sector as percentage of GDP reported by the World Bank Development Report.

$R I S K_{i}$ indicates the investment risk for country $i$ focusing attention on the investment profile subcomponents reported by PRS Group’s International Country Risk Guide (ICRG). Specifically, it takes into account contract viability, profits repatriation and payments delays.

$\gamma_{t}$ indicates time effects;

$u_{i}$ indicates countries' effects;

$\varepsilon_{i t}$ is the stochastic residuals.

Some clarifications are required on Bankruptcy Law and its enforcement.

With respect to Bankruptcy Law, the research does not explicitly consider the several bankruptcy provisions that are likely to affect the resolution of financial distress. The main goal here is not to evaluate if some bankruptcy procedures are better than others or in which countries they should be applied. The objective is to analyse if, and to what extent, the degree of sophistication of the bankruptcy law and its enforcement can affect total amount of investment in a country ${ }^{12}$.

Furthermore, to evaluate the efficiency of a bankruptcy system both the liquidation and the reorganization efficiency should be taken into account. Good bankruptcy laws close unviable business and reorganize viable ones thus regulating more efficiently the insolvency proceedings

\footnotetext{
${ }^{9}$ The cost is calculated by World Bank on the basis of survey responses by practicing insolvency lawyers. If several respondents report different estimates, the median reported value is used (see Data Notes in World Bank Doing Business 2008 for details).

${ }^{10}$ The calculation takes into account whether the business is kept as a going concern during the proceedings, as well as bankruptcy costs and the loss in value due to the time spent closing down used (see Data Notes in World Bank Doing Business 2008 for details).

${ }^{11}$ When Gross National Saving is not explicitly reported on Economic Activity table of the Selected Development Indicators, it is calculated by subtracting Household final consumption expenditure and General Government final consumption expenditure to GDP.

${ }^{12}$ The problem of multicollinearity has been taken into account by testing the correlation between the sophistication degree of the Bankruptcy Law and the enforcement rank. The correlation, significant at the 1\% level, equals -0.28 .
} 
(World Bank, Doing Business Report 2007). Nevertheless, the analysis actually considers "closing a business" enforcement as proxy for bankruptcy system efficiency since reorganization rates (ratio of the number of firms in a reorganization procedure to the total number of bankrupt firms), as well as success rates (ratio of the number of firms that reorganize successfully to the total number of bankrupt firms), are low around the world ${ }^{13}$. As pointed out by Couwenberg (2001), the overwhelming majority of the insolvency proceedings around the world concerns liquidation. Moreover, data on reorganization and success rates are not available for all countries and/or over the whole considered period.

Therefore, $E N F_{i}$ indicates the "closing a business" enforcement rank provided by the World Bank and is assumed to be a reliable indicator of the insolvency efficiency in general. Low values mean that a country reaches the top positions in the international ranking and rigorously enforces bankruptcy procedures (high efficiency) ${ }^{14}$.

The efficiency of a bankruptcy system can be evaluated for the three stages of the bankruptcy process (Couwenberg and de Jong 2008; Franks et al. 1996). The ex ante efficiency (first stage) aims to provide incentives for entrepreneurs to limit the usage of the legal procedures for bankruptcy. The interim efficiency (second stage) takes place during the financial distress, when the bankruptcy procedure is tainted by conflicts of interest of participants. The ex post efficiency (third stage) is achieved if all creditors and other parties receive the highest payouts in accordance with contractual rights". Therefore, efficiency arise when bankruptcy process costs are low, recovery rates are high and distribution are driven by priority rules. Since several difficulties arise in the study of the first and the second stages of the bankruptcy process, this study focuses attention on the third phase of the bankruptcy process that can be analysed by considering specific efficiency proxies.

Following Islam (1995) and Caselli et al. (1996), the 1992-2006 period is split into sub-periods of span $\tau^{15}$. We adopt 3-year time periods, hence we obtain 5 observations for each country ${ }^{16}$ (19921994; 1995-1997; 1998-2000; 2001-2003; 2004-2006).

For details on variables, data sources and summary statistics see the appendix (table A2 and table A3).

\section{Empirical Results}

Section 4 presents empirical evidence on the legal determinants of investment share of GDP. The results of equation (1) estimation over the 1990-2006 period are reported on table 2, which considers all countries, and table 3, which distinguishes between rich and poor countries ${ }^{17}$.

\footnotetext{
${ }^{13}$ In Italy, for example, only $2 \%$ of the insolvency proceedings concerned the "Concordato Preventivo", which is a recovery procedure, while $97 \%$ of them concerned liquidation, at least before the Bankruptcy reform adopted in recent years (legge delega n.80/2005) (Franzoni and Marchesi 2006).

${ }^{14}$ Note however that, as explained by Blazy et al. (2008), World Bank data cannot serve as proxy for differences in courts' selection errors (type-I/type-II) between countries. In fact, “... some economically inefficient failing firms (which should have been liquidated) mistakenly may be categorized as efficient and allowed to reorganize (type-I error). Conversely, type-II errors occur when some economically efficient but failing firms may liquidate in bankruptcy, either because no reorganization procedure exists or because a procedure exists but some efficient firms are mistakenly categorized as inefficient”.

${ }^{15}$ The advantage of shorter time periods is the availability of a greater number of data, but the cost is that cyclical or short-run effects can bias the results through serial correlation of the errors. In our analysis we assume that there is no $\tau$-order serial correlation $E\left[\varepsilon_{i, t} \varepsilon_{i, t-\tau}\right]=0$.

${ }^{16}$ Final observations are given by the annual average values for each 3-year period. When only one year data is available for a specific sub-period, it is considered as the average value for the interval.
} 
Table 2 Bankruptcy system and Investment Share of GDP (1992-2006), All Countries

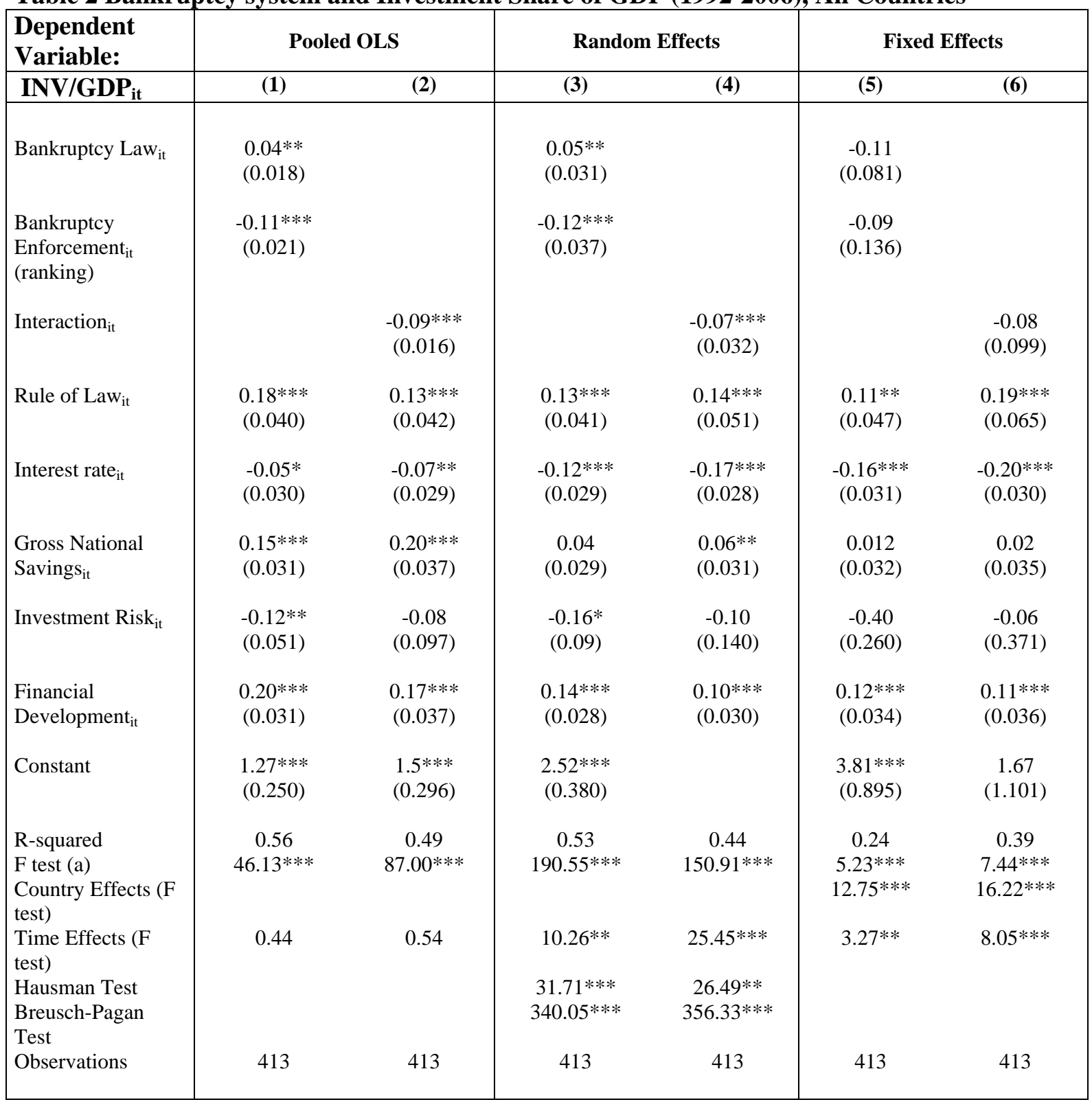

(a) It refers to Wald test when random effect model is considered

All variables are considered in log (except dummy variables), so that estimations can be considered as elasticities Standard errors in parenthesis

$*, * *, * * *$, for $10 \%, 5 \%$ and $1 \%$ significance level respectively

\footnotetext{
${ }^{17}$ The classification of the economies is based on the World Bank Development Report. More specifically, the World Bank classifies the economies by income per capita and by region. GNI per capita is used to determine the following income classifications: low-income, $\$ 875$ or less in 2005; middle-income, $\$ 876$ to $\$ 10,725$; and high-income, $\$ 10,726$ and above. A further division at GNI per capita $\$ 3,465$ is made between lower-middle-income and upper-middle income economies (World Development Report, 2008).
} 
Table 3 Bankruptcy system and Investment Share of GDP (1992-2006), Rich and Poor Countries

\begin{tabular}{|c|c|c|c|c|c|c|c|c|c|c|c|c|}
\hline \multirow{3}{*}{\begin{tabular}{|l|}
$\begin{array}{l}\text { Dependent } \\
\text { Variable: }\end{array}$ \\
INV/GDP $_{\text {it }}$
\end{tabular}} & \multicolumn{4}{|c|}{ Pooled OLS } & \multicolumn{4}{|c|}{ Random Effects } & \multicolumn{4}{|c|}{ Fixed Effects } \\
\hline & \multicolumn{2}{|c|}{ Rich } & \multicolumn{2}{|c|}{ Poor } & \multicolumn{2}{|c|}{ Rich } & \multicolumn{2}{|c|}{ Poor } & \multicolumn{2}{|c|}{ Rich } & \multicolumn{2}{|c|}{ Poor } \\
\hline & (1) & (2) & (3) & (4) & (5) & (6) & (7) & (8) & (9) & (10) & (11) & (12) \\
\hline $\begin{array}{l}\text { Bankruptcy } \\
\text { Lawit }_{\text {it }}\end{array}$ & $\begin{array}{c}-0.03 \\
(0.023)\end{array}$ & & $\begin{array}{l}0.09 * * * \\
(0.030)\end{array}$ & & $\begin{array}{c}-0.04 \\
(0.040)\end{array}$ & & $\begin{array}{l}0.12 * * \\
(0.051)\end{array}$ & & $\begin{array}{c}0.08 \\
(0.070)\end{array}$ & & $\begin{array}{c}0.09 * \\
(0.045)\end{array}$ & \\
\hline $\begin{array}{l}\text { Bankruptcy } \\
\text { Enforcement }_{\text {it }} \\
\text { (ranking) }\end{array}$ & $\begin{array}{c}-0.11^{* * *} \\
(0.020)\end{array}$ & & $\begin{array}{c}-0.12 * * \\
(0.067)\end{array}$ & & $\begin{array}{c}-0.03 \\
(0.124)\end{array}$ & & $\begin{array}{c}-0.17 \\
(0.141)\end{array}$ & & $\begin{array}{l}-0.07 * * \\
(0.039)\end{array}$ & & $\begin{array}{l}-1.31^{* *} \\
(0.654)\end{array}$ & \\
\hline Interaction $_{\text {it }}$ & & $\begin{array}{c}-0.10^{* * * *} \\
(0.017)\end{array}$ & & $\begin{array}{c}-0.20 \\
(0.049)\end{array}$ & & $\begin{array}{l}-0.07 * * \\
(0.037)\end{array}$ & & $\begin{array}{l}0.10^{* *} \\
(0.065)\end{array}$ & & $\begin{array}{c}-0.14 * * * \\
(0.050)\end{array}$ & & $\begin{array}{l}-0.26 \\
(0.59)\end{array}$ \\
\hline Rule of $\mathrm{Law}_{\text {it }}$ & $\begin{array}{l}0.08^{* *} \\
(0.067)\end{array}$ & $\begin{array}{l}0.09 * * \\
(0.067)\end{array}$ & $\begin{array}{l}0.15^{* *} \\
(0.061)\end{array}$ & $\begin{array}{c}0.23 * * * \\
(0.065)\end{array}$ & $\begin{array}{l}0.13^{* *} \\
(0.072)\end{array}$ & $\begin{array}{c}0.13 * \\
(0.072)\end{array}$ & $\begin{array}{l}0.13^{* *} \\
(0.060)\end{array}$ & $\begin{array}{l}0.36^{* *} \\
(0.141)\end{array}$ & $\begin{array}{c}0.25^{* * * *} \\
(0.093)\end{array}$ & $\begin{array}{c}0.07^{*} \\
(0.118)\end{array}$ & $\begin{array}{c}0.10^{*} \\
(0.063)\end{array}$ & $\begin{array}{c}0.23 * * \\
(0.10)\end{array}$ \\
\hline Interest rate $_{i t}$ & $\begin{array}{l}-0.06^{*} \\
(0.034)\end{array}$ & $\begin{array}{l}-0.06 * * \\
(0.031)\end{array}$ & $\begin{array}{l}0.14^{* *} \\
(0.056)\end{array}$ & $\begin{array}{l}0.16^{* *} \\
(0.062)\end{array}$ & $\begin{array}{c}-0.19 * * * \\
(0.031)\end{array}$ & $\begin{array}{c}-0.19 * * * \\
(0.031)\end{array}$ & $\begin{array}{c}-0.03 \\
(0.060)\end{array}$ & $\begin{array}{c}-0.08 \\
(0.075)\end{array}$ & $\begin{array}{c}-0.22 * * * \\
(0.034)\end{array}$ & $\begin{array}{l}-0.27^{*} \\
(0.140)\end{array}$ & $\begin{array}{c}-0.06 \\
(0.068)\end{array}$ & $\begin{array}{l}-0.08 \\
(0.06)\end{array}$ \\
\hline $\begin{array}{l}\text { Gross National } \\
\text { Savings }_{\text {it }}\end{array}$ & $\begin{array}{l}0.10^{* *} \\
(0.043)\end{array}$ & $\begin{array}{l}0.10^{* *} \\
(0.042)\end{array}$ & $\begin{array}{l}0.09 * * \\
(0.045)\end{array}$ & $\begin{array}{c}0.20 * * * \\
(0.066)\end{array}$ & $\begin{array}{l}0.09 * * \\
(0.044)\end{array}$ & $\begin{array}{l}0.09 * * \\
(0.043)\end{array}$ & $\begin{array}{c}0.02 \\
(0.041)\end{array}$ & $\begin{array}{c}0.22 \\
(0.279)\end{array}$ & $\begin{array}{l}0.10^{* *} \\
(0.047)\end{array}$ & $\begin{array}{l}0.28 * * \\
(0.144)\end{array}$ & $\begin{array}{c}-0.62 \\
(0.046)\end{array}$ & $\begin{array}{l}-0.05 \\
(0.05)\end{array}$ \\
\hline $\begin{array}{l}\text { Investment } \\
\text { Risk }_{\text {it }}\end{array}$ & $\begin{array}{c}-0.28^{* * *} \\
(0.103)\end{array}$ & $\begin{array}{c}-0.28 * * * \\
(0.102)\end{array}$ & $\begin{array}{c}-0.12 * * \\
(0.060)\end{array}$ & $\begin{array}{c}0.05 \\
(0.188)\end{array}$ & $\begin{array}{l}-0.25 \\
(0.16)\end{array}$ & $\begin{array}{l}-0.25 \\
(0.16)\end{array}$ & $\begin{array}{c}-0.23 \\
(0.148)\end{array}$ & $\begin{array}{c}-0.32 \\
(0.530)\end{array}$ & $\begin{array}{l}-0.72 * * \\
(0.433)\end{array}$ & $\begin{array}{l}-0.43^{*} \\
(0.258)\end{array}$ & $\begin{array}{c}-0.49 \\
(0.365)\end{array}$ & $\begin{array}{l}-1.20 \\
(0.77)\end{array}$ \\
\hline $\begin{array}{l}\text { Financial } \\
\text { Development }_{\text {it }}\end{array}$ & $\begin{array}{c}0.21^{* * *} \\
(0.039)\end{array}$ & $\begin{array}{c}0.21^{* * *} \\
(0.040)\end{array}$ & $\begin{array}{c}0.19 * * * \\
(0.057)\end{array}$ & $\begin{array}{c}0.08 \\
(0.090)\end{array}$ & $\begin{array}{l}0.10^{* * *} \\
(0.037)\end{array}$ & $\begin{array}{c}0.10^{* * *} \\
(0.037)\end{array}$ & $\begin{array}{c}0.14 * * * \\
(0.046)\end{array}$ & $\begin{array}{l}0.41 * * \\
(0.121)\end{array}$ & $\begin{array}{l}0.09 * * \\
(0.044)\end{array}$ & $\begin{array}{c}0.11 \\
(0.198)\end{array}$ & $\begin{array}{l}0.14 * * * \\
(0.054)\end{array}$ & $\begin{array}{c}0.10 \\
(0.065)\end{array}$ \\
\hline Constant & $\begin{array}{l}2.5^{* * *} \\
(0.331)\end{array}$ & $\begin{array}{l}2.5^{* * *} \\
(0.313)\end{array}$ & $\begin{array}{c}0.95^{*} \\
(0.552)\end{array}$ & $\begin{array}{c}0.29 \\
(0.562)\end{array}$ & $\begin{array}{c}3.09 * * * \\
(0.54)\end{array}$ & $\begin{array}{c}3.04 * * * \\
(0.53)\end{array}$ & $\begin{array}{c}2.49 * * * \\
(0.86)\end{array}$ & $\begin{array}{l}2.03 * * \\
(0.98)\end{array}$ & $\begin{array}{c}0.25 \\
(1.35)\end{array}$ & $\begin{array}{l}2.03 * * \\
(0.98)\end{array}$ & $\begin{array}{l}7.68^{* *} \\
(3.04)\end{array}$ & $\begin{array}{c}5.56 \\
(3.47)\end{array}$ \\
\hline R-squared & 0.52 & 0.51 & 0.35 & 0.27 & 0.48 & 0.48 & 0.31 & 0.32 & 0.31 & 0.34 & 0.16 & 0.18 \\
\hline F test (a) & $56.66 * * *$ & $\begin{array}{c}66.85^{* *} \\
*\end{array}$ & $\begin{array}{c}10.42 * * \\
*\end{array}$ & $4.78 * * *$ & $\begin{array}{c}127.81^{* *} \\
*\end{array}$ & $\begin{array}{c}127.58^{*} \\
* *\end{array}$ & $\begin{array}{c}35.44^{* *} \\
*\end{array}$ & $\begin{array}{c}32.36^{* *} \\
*\end{array}$ & $7.35 * * *$ & $8.00 * * *$ & $2.48 * *$ & \\
\hline $\begin{array}{l}\text { Country Effects } \\
\text { (F test) }\end{array}$ & & & & & & & & & $\begin{array}{c}13.66^{* *} \\
*\end{array}$ & $\begin{array}{c}13.80^{* *} \\
*\end{array}$ & $\begin{array}{c}10.10^{* *} \\
*\end{array}$ & $\begin{array}{l}19.84^{* *} \\
*\end{array}$ \\
\hline $\begin{array}{l}\text { Time Effects } \\
\text { (F test) } \\
\text { Breusch-Pagan } \\
\text { Test } \\
\text { Hausman Test }\end{array}$ & 0.86 & 1.28 & 0.08 & 0.59 & $\begin{array}{c}17.30^{* * *} \\
237.53^{* *} \\
* \\
19.05^{* *}\end{array}$ & $\begin{array}{c}17.63^{* *} \\
* \\
242.76 * \\
* * \\
16.74 *\end{array}$ & $\begin{array}{c}10.25 * * \\
113.68 * \\
* * \\
5.52\end{array}$ & $\begin{array}{c}18.14^{* *} \\
* \\
99.63^{* *} \\
* \\
7.78\end{array}$ & $4.92 * * *$ & $5.44 * * *$ & 0.62 & $5.18^{* *}$ \\
\hline Observations & 264 & 264 & 149 & 149 & 264 & 264 & 149 & 149 & 264 & 264 & 149 & 149 \\
\hline
\end{tabular}

(a) It refers to Wald test when random effect model is considered

All variables are considered in log (except dummy variables), so that estimations can be considered as elasticities Standard errors in parenthesis

*, **, ***, for $10 \%, 5 \%$ and $1 \%$ significance level respectively

Let us analyse the evidence on the legal determinants of Investment share of Gross Domestic Product. As shown in Table 2, the F test null hypothesis that all the coefficients are jointly equal to zero is always rejected at 1 percent level.

The pooled cross-section specification might generate biased and inconsistent results, since it does not take into account unobserved heterogeneity among countries with respect to, for example, managerial ability, degree of risk-aversion, legal origin, institutional framework, etc. The Breusch- 
Pagan test, in fact, indicates that pooled cross-section is not the correct specification of the model. The null hypothesis ${ }^{18}$ is rejected both when all countries are considered (table 2) and when rich and poor countries are analysed separately (table 2), indicating that individual shocks should be taken into account.

The Hausman specification test ${ }^{19}$ is then performed to investigate the correlation between the unobserved individual effect and the observed explanatory variables. As reported in table 2, we reject the null hypothesis; therefore the correct specification of the model is fixed effect when all countries are considered together (table 2, reg (5)). However, legal variables are not significant.

When we distinguish between rich and poor countries, some differences arise. The correct specification of the model is Fixed effects for rich countries (table 3, reg (9)). and Random Effects for poor countries (table 3, reg (7)) ${ }^{20}$.

Bankruptcy Law enters positively but not significantly for rich countries, while Bankruptcy enforcement rank enters at 5 percent level with the expected negative sign. The higher the judicial efficiency (low ranking) the higher the investment share of GDP.

In rich countries, characterized by relatively complex insolvency systems and somehow convergent bankruptcy reforms (Stanghellini 2007), the investment share of GDP would be influenced by expected enforcement of bankruptcy procedures more than the degree of sophistication of the Bankruptcy Law. Legal production is sufficiently high in rich countries, and overlapping laws have sometimes decelerated the civil justice and increased the costs of the insolvency proceedings. In some circumstances, the excessive degree of sophistication of the bankruptcy Law has determined more costs than expected advantages.

The degree of sophistication of the Bankruptcy Law and the Bankruptcy enforcement have the expected sign also when poor countries' investments are considered (table 3, reg (7)), however only bankruptcy law enters significantly at 5 percent level. The result could be partially explained by the fact that poor countries usually have very simple debt enforcement proceedings. When bankrupts are expected to be punished too quickly and severely, entrepreneurs may be discouraged from taking the financial risks needed to make their investments, as well as letting off defaulting debtors too readily may discourage potential creditors because of moral hazard. Therefore, at the least a certain degree of sophistication of the Bankruptcy Law is desirable to guarantee creditors and make investments possible.

Rule of Law enters positively and significantly both for rich and poor countries.

All other explanatory variables enter significantly with the expected sign when the analysis focuses attention on rich countries (table 3, reg (9)). Interest rate enters negatively and significantly at the 1 percent level showing that high interest rate is associated with low investment levels. Gross National Savings and Financial Development are positively and significantly associated with total amount of investment as percentage of GDP.

When poor countries are considered, Interest Rate, Gross National Savings, Investment Risk and Financial Development enter with the expected sign but only Financial development is significant at the 1 percent level (table 3, reg (7)).

The $\mathrm{F}$ test on the time dummies variables allows us to reject the hypothesis that all the coefficient are jointly equal to zero.

\footnotetext{
${ }^{18}$ The null hypothesis of the Breush-Pagan test is that the groupwise variance is equal to zero. Under the null, there are not individual shocks and OLS estimation produce unbiased results. Otherwise, fixed or random effect models have to be used.

${ }^{19}$ The null hypothesis of the Hausman test is "Ho: difference in coefficients not systematic". Under the null, the correlation between the unobserved individual effects and the explanatory variables is zero. Hence, the correct specification of the model is Random Effect, which obtains efficient and consistent estimates.

${ }^{20}$ The null hypothesis of the Hausman test is rejected (Prob $>$ chi2 $=0.03$ ) for rich countries while it is not rejected (Prob $>$ chi2 $=0.51)$ for poor countries.
} 


\subsubsection{The Interaction effect}

Regressions (2), (4), (6) in table 2, (2), (4), (6), (8), (10), (12) in table 3 include the Interaction term between Bankruptcy Law and Bankruptcy Enforcement. Bambor et al. (2006) argue that analysts should include each of the elements that constitute the interaction term when specifying multiplicative interaction models, except in some circumstances that, however, are satisfied in our research. The first necessary condition that must be met before omitting constitutive terms without obtaining significant inferential errors is that "...the analyst has a strong expectation that the omitted variable has no effect on the dependent variable in the absence of the other modifying variable” (Brambor et al. 2006, p. 68). In our analysis, we expect that bankruptcy law has no effect on the investment share of GDP when enforcement is zero, as well as insolvency enforcement has no effect on the investment share of GDP if the bankruptcy law does not exist. The second condition that must be met before omitting constitutive terms is that the analyst should estimate the fully specified model (with the interaction and all constitutive terms) and find that the coefficient of the omitted variable is zero. As shown in table A4 in the appendix, the coefficients of the omitted variables are near to zero when all constitutive terms are included in the model.

Therefore, the model becomes:

$$
\frac{I N V}{G D P_{i t}}=\beta_{0}+\beta_{1}\left(B A N K F^{*} E N F\right)_{i t}+\beta_{2} R U L E_{t t}+\beta_{3} I N T_{i t}+\beta_{4} R I S K_{t t}+\beta_{5} S A V_{i t}+\beta_{6} F I N_{i t}+\beta_{7} R I S K_{i t}+\gamma_{t}+u_{i}+\varepsilon_{i t}
$$

$t=1992, \ldots, 2006 \quad i=1, \ldots, 91$ countries

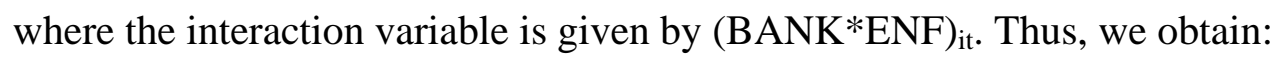

$$
\frac{\partial \frac{I N V}{G D P} P_{i t}}{\partial B A N K R_{i t}}=\beta_{1} E N F_{i t} \quad \text { and } \quad \frac{\partial \frac{I N V}{G D P}}{\partial E N F_{i t}}=\beta_{1} B A N K R_{i t}
$$

The effect of the Bankruptcy Law on the investment share of GDP depends on the procedures efficiency, as well as the effect of the law enforcement on investment share of GDP depends on the degree of sophistication of the Bankruptcy Law. One expects that the bankruptcy law has no effect if there is no enforcement in a country (i.e. because of corruption, a war or a revolution), as well as analysing the efficiency makes no sense if no Bankrupt regulation is adopted in a country.

Previous empirical studies (Claessens and Klapper 2005) found that countries characterized by weak and simple bankruptcy law have answered by rigorously enforcing insolvency procedures (substitution effect). Our analysis partially confirms this evidence by finding contrasting results depending on the development level of each country.

More specifically, the interaction term enters negatively and significantly at the 1 percent level for rich countries (table 3, reg(10)). When the enforcement rank decreases (higher efficiency), the effect of the Bankruptcy Law on the investment share of GDP increases. On the contrary, if the enforcement rank increases (lower efficiency), the effect of Bankruptcy Law on the investment share of GDP decreases. Estimation results would therefore suggest some complementary effect between the quality of the law and the quality of the enforcement in rich countries. This means that legal production does not determine the expected results if it is not well enforced. Bankruptcy reforms should be accompanied by enforcement improvements in rich countries, where the legal production is high enough. According to the World Bank "...a country that wants efficient bankruptcy should regulate only what it can enforce. Sophisticated reorganization procedures work 
in rich countries, with experienced judges and lawyers and a liquid market for the assets of reorganizing firms” (Doing Business 2007).

The interaction term enters positively and significantly at the 5 percent level when poor countries are considered (table 3, reg(8)). The effect of the Bankruptcy Law on the investment share of GDP decreases when the enforcement rank decreases (higher efficiency), suggesting a certain degree of substitution between the quality of the law and its enforcement. We find that countries characterized by weak bankruptcy law have reacted by rigorously enforcing insolvency procedures.

To summarize, below a certain level of per-capita GDP a substitution effect prevails between Bankruptcy Law and Bankruptcy Enforcement. On the contrary, empirical evidence would suggest some complementary effect between the quality of the law and the quality of the enforcement in richer countries.

\subsubsection{Dealing with endogeneity}

As it is known, fixed effects in panel data model allow us to solve the omitted variable problem by controlling for the unobservable individual effect but, because of simultaneity, the endogeneity problem is still present. One could think that also the investment share of GDP determines the degree of sophistication of the bankruptcy law and its enforcement. More specifically, the bankruptcy law and its efficiency, as well as the other potential endogenous explanatory variables, could be determined jointly with the dependent variable.

The traditional approach to solve the endogeneity problem consists in instrumental variables regression with external instruments ${ }^{21}$ and fixed or random effects estimators (depending on the existence of some correlation between the unobserved effect and the explanatory variables).

Focusing attention on our variables of interest, reasonable instruments for enforcement rank and bankruptcy law could be adopted.

Possible external instruments for bankruptcy enforcement include, for example, the ratio between total number of firms in a bankruptcy procedure and total number of firms, judges' productivity and total number of courts in each country.

With regard to the ratio between total number of firms in a bankruptcy procedure and total number of firms, empirical studies have shown that the higher the efficiency of the bankruptcy procedure the higher the number of firms that enter the bankruptcy procedure, reach an agreement on a reorganization plan and successfully survive (Claessens and Klapper 2005). A proxy for judges' productivity could be the ratio between the total number of sentences and the total number of judicial proceedings (in a calendar year). The third cited instrument could be more problematic since many questions concern the relationship between the number of courts and judicial enforcement. One could think that the higher the number of courts the higher the judicial system efficiency. Nevertheless, some studies suggest to reduce the number of courts by increasing their size. Higher enforcement is reached in larger size courts because of economies of scale and judges' specialization (Franzoni and Marchesi 2006).

With respect to Bankruptcy Law, a possible instrument might be the survival rates of firms in a Bankruptcy procedure. Empirical evidence shows higher survival rates in reorganization based systems (Couwenberg 2001). Another instrumental variable for Bankruptcy Law might be the legal origin of the judicial system (La Porta et al. 1998). Blazy et al. (2008), in fact, show that Bankruptcy models may differ across countries because they come from different legal families. Also labour market rigidity influences investment share of GDP through Bankruptcy regulation.

\footnotetext{
${ }^{21}$ In an equation with an endogenous explanatory variable, an instrumental variable is a variable that does not appear in the equation, is uncorrelated with the error in the equation and is (partially) correlated with the endogenous explanatory variable (Wooldridge 2002).
} 
Blazy et al. (2008) show that the social pro debtor model performs in countries within which the legal protection of workers are the more severe. The legal protection of workers may serve to understand why some bankruptcy models promote continuation of firms' operations, or allow for deviations from absolute priority rule in favour of workers.

Nevertheless, several problems arise when we try to follow the standard approach with external instrumental variables since data are not available for all considered countries and/or over the whole analysed period.

An alternative approach to tackle the endogeneity issue uses internal instruments by exploiting panel data structure. More specifically, we use a Generalized Method of Moment (GMM) estimator (Arellano and Bond 1991; Blundell and Bond 1998) treating all explanatory variables as potentially endogenous. Thus, we rewrite eq.(1) in dynamics terms, as follows:

$$
\frac{I N V}{G D P_{i t}}=\beta_{0}+\beta_{1} \frac{I N V}{G D P_{i t-1}}+\beta_{2} B A N K R+\beta_{3} E N F_{i t}+\beta_{4} R U L E_{i t}+\beta_{5} I N T_{i t}+\beta_{6} S A V_{i t}+\beta_{7} F I N_{i t}+\beta_{8} R I S K_{t t}+\gamma_{t}+u_{i}+\varepsilon_{i t}
$$

Eq.(3) is a dynamic panel model with fixed effects and a lagged dependent variable which allows us to take into account the dynamic nature of the investments ${ }^{22}$. It can be properly estimated through the first differences GMM (GMM-DIFF) estimator proposed by Arellano and Bond (1991) which uses all the available lags of each independent variable in levels as instruments. However, the levels are poor instruments when variables exhibit strong persistence, as in the analysed model (weak instruments). For this reason, we employ the estimation of the system of equations (GMM-SYS) implemented by Blundell and Bond (1998). It combines the first differenced regression used in GMM-DIFF and the eq.(3) in levels, whose instruments are the lagged differences of the endogenous variables ${ }^{23}$.

The choice of the endogenous variables and the lags has been performed through the Difference-inSargan test. The endogenous variable is Financial Development for which the t-2 and t-3 lags have been used, while t-3 lag has been used for the lagged investment share of GDP. Table 4 shows the empirical results. The Null hypothesis of the Hansen test is not rejected for all estimations, therefore the instruments satisfy the orthogonality condition required for their appropriateness. Moreover, we report the results of the tests proposed by Arellano and Bond (1991) to detect first and second-order serial correlation in the residuals. If $\varepsilon_{i t}$ are not serially correlated, the differenced residuals should show autocorrelation of first-order and absence of second-order serial correlation. As shown in table 4 , the absence of second-order serial correlation, which is a necessary condition for the validity of the instruments, is satisfied in our analysis.

The coefficient of the lagged dependent variable is significant with a positive sign both for rich and poor countries showing the opportunity of the dynamic specification of the model. With respect to the other explanatory variables, the GMM-System confirms our previous estimation results. The degree of sophistication of the Bankrupt Law enters positively both for poor and rich countries, but it is not significant for the last ones. The enforcement rank enters negatively, therefore low enforce rank (high efficiency) is associated with high investment share of GDP, but it is significant at the 1 percent level only for rich countries. Rule of Law enters positively and significantly both for rich and poor countries.

All other explanatory variables enter with the expected sign but the interest rate is not significant for poor countries while financial development is not significant for rich countries.

\footnotetext{
${ }^{22}$ Note that the introduction of the lagged dependent variable implies that both the OLS and Fixed Effects estimates are biased because of the correlation between the lagged dependent variable and the error term.

${ }^{23}$ For details, see Roodman (2006).
} 
Table 4 Empirical results of the dynamic panel data model: GMM-System

\begin{tabular}{|c|c|c|c|}
\hline $\begin{array}{l}\text { Dependent Variable: } \\
\text { INV/GDP }_{\text {it }}\end{array}$ & $\begin{array}{l}\text { All } \\
\text { (1) }\end{array}$ & $\begin{array}{l}\text { Rich } \\
\text { (2) }\end{array}$ & $\begin{array}{l}\text { Poor } \\
\text { (3) }\end{array}$ \\
\hline $\mathrm{INV} / \mathrm{GDP}_{\mathrm{it}-1}$ & $\begin{array}{c}0.82 \\
(0.035)\end{array}$ & $\begin{array}{c}0.72 \\
(0.097)\end{array}$ & $\begin{array}{c}0.74 \\
(0.0929\end{array}$ \\
\hline Bankruptcy Law it & $\begin{array}{c}0.04 \\
(0.048)\end{array}$ & $\begin{array}{c}0.05 \\
(0.066)\end{array}$ & $\begin{array}{c}0.07 * \\
(0.040)\end{array}$ \\
\hline $\begin{array}{l}\text { Bankruptcy } \\
\text { Enforcement }_{\text {it }} \text { (ranking) }\end{array}$ & $\begin{array}{c}-0.07 \\
(0.045)\end{array}$ & $\begin{array}{c}-0.14^{* * *} \\
(0.048)\end{array}$ & $\begin{array}{l}-0.06 \\
(0.066)\end{array}$ \\
\hline Rule of $\mathrm{Law}_{\mathrm{it}}$ & $\begin{array}{c}0.04 \\
(0.087)\end{array}$ & $\begin{array}{c}0.07^{*} \\
(0.118)\end{array}$ & $\begin{array}{l}0.26^{* *} \\
(0.108)\end{array}$ \\
\hline Interest rate $_{i t}$ & $\begin{array}{c}0.02 \\
(0.059)\end{array}$ & $\begin{array}{l}-0.19 * * \\
(0.076)\end{array}$ & $\begin{array}{l}-0.07 \\
(0.070)\end{array}$ \\
\hline Gross National Savings & $\begin{array}{c}0.23 \\
(0.190)\end{array}$ & $\begin{array}{l}0.27 * * \\
(0.148)\end{array}$ & $\begin{array}{l}0.27 * * \\
(0.108)\end{array}$ \\
\hline Investment Risk $\mathrm{it}_{\mathrm{it}}$ & $\begin{array}{l}-0.11 \\
0.154\end{array}$ & $\begin{array}{l}-0.43^{*} \\
(0.251)\end{array}$ & $\begin{array}{l}-0.16^{*} \\
(0.090)\end{array}$ \\
\hline Financial Development $_{\text {it }}$ & $\begin{array}{c}0.40^{* * *} \\
(0.150)\end{array}$ & $\begin{array}{c}0.12 \\
(0.197)\end{array}$ & $\begin{array}{l}0.04^{*} \\
(0.139)\end{array}$ \\
\hline Constant & $\begin{array}{l}-0.00 \\
(0.081)\end{array}$ & $\begin{array}{c}0.05 \\
(0.096)\end{array}$ & $\begin{array}{c}0.53 \\
(0.940)\end{array}$ \\
\hline $\begin{array}{l}\text { Time Effects } \\
\text { (F test) } \\
\text { Hansen test (p-value) } \\
\text { AR (1) } \\
\text { AR (2) } \\
\text { Observations }\end{array}$ & $\begin{array}{c}11.73 * * \\
0.48 \\
-3.50 * * * \\
0.52 \\
338\end{array}$ & $\begin{array}{c}11.36 * * \\
0.27 \\
-4.65^{* * *} \\
0.58 \\
216\end{array}$ & $\begin{array}{c}11.78 * * \\
0.10 \\
-2.25 * * * \\
-0.36 \\
122\end{array}$ \\
\hline
\end{tabular}

Robust standard errors in parenthesis

$*, * *, * * *$, for $10 \%, 5 \%$ and $1 \%$ significance level respectively

\section{Conclusions}

The aim of the paper is to examine whether and to what extent cross-country differences in the Bankruptcy law and its efficiency explain cross-country differences in the level of investment share of GDP. Answering this question has important policy implications, given the current legislative and regulatory responses to lending practices and bankruptcy protection.

Empirical evidence suggests that both the sophistication degree of the Bankruptcy Law and the efficiency of the insolvency proceedings are positively associated with the investment share of gross domestic product.

In rich countries, however, the degree of sophistication of the Bankruptcy Law is not significant. The investment share of GDP would be influenced by the expected enforcement of bankruptcy procedures more than the Bankruptcy Law. Legal production is sufficiently high and overlapping laws have often decelerated the civil justice and increased the costs of the insolvency proceedings. 
When poor countries' investments are considered, bankruptcy law enters significantly with the expected positive sign. The result could be partially explained by the fact that poor countries usually have very simple debt enforcement proceedings. These very simple proceedings are usually well enforced, but they do not distinguish among different insolvency situations. When bankrupts are expected to be punished too quickly and severely, entrepreneurs may be discouraged from taking the financial risks needed to make their investments, as well as letting off defaulting debtors too readily may discourage potential creditors because of moral hazard. Therefore, a certain degree of sophistication of the Bankruptcy Law is desirable to guarantee creditors and make investments possible.

Furthermore, estimation results would suggest some complementary effect between the quality of the law and the quality of the enforcement in rich countries. Legal production does not determine the expected results if it is not well enforced, hence reforms aimed at improving application of law would be more desirable than reforms that increase legal production with the frequent result of decelerating the judicial system. On the contrary, the interaction term indicates some substitution effect in poor countries, suggesting that countries characterized by weak bankruptcy law have answered by rigorously enforcing insolvency procedures.

The paper suggests interesting directions for future research. The analysis covers the 1992-2006 period. In the following years, several reforms of the bankruptcy procedures have been adopted around the world. It would be motivating to evaluate the effects of these reforms in order to investigate if there is a process of convergence among different bankruptcy systems. It would also be appealing to find out if, and to what extent, the obtained results vary if we distinguish among different sectors. Furthermore, because of the current international financial crisis, many households and firms are likely to go under. For a given degree of sophistication of the Bankruptcy Law, it would be interesting to compare and evaluate different governments' plans applied to solve or avoid the increasing cases of household over-indebtedness, firms' bankruptcy and some industries' potential collapse.

\section{References}

Aghion, P., Bolton, P. (1992). An "Incomplete Contracts" Approach to Financial Contracting. Review of Economic Studies, 59, 473-494.

Ayotte, K., Yun, H. (2007). Matching Bankruptcy Laws to Legal Environment. Journal of Law, Economics \& Organization, doi:10.1093/jleo/ewm048.

Arellano, M., Bond, S. (1991). Some Tests of Specification for Panel Data: Monte Carlo Evidence and an Application to Employment Equations. Review of Economic Studies, 58, 277-297.

Armour, J., Hsu, A., Walters, A. (2006). The costs and benefits of secured creditor control in bankruptcy: Evidence from the UK. Centre for Business Research, University of Cambridge, Working Paper no.332.

Baird, D., Bris, A., Zhu, N. (2005). The dynamics of large and small Chapter 11 cases: An empirical study. Yale ICF Working paper no. 05-29.

Berglof, E., von Thadden, E.L. (1994). Short-Term versus Long-Term Interests: Capital Structure with Multiple Investors. Quarterly Journal of Economics, 109, 1055-84.

Betker, B.L. (1995). An empirical examination of prepackaged bankruptcy. Financial Management, 24, 3-18. Betker, B.L. (1997). The administrative costs of bankruptcy: Some recent evidence. Financial Management, 26, 56-68.

Blazy, R., Chopard, B., Fimayer, A. (2008). Bankruptcy law: a mechanism of governance for financially distressed firms. European Journal of Law and Economics, 25, 253-267.

Blundell, R., Bond, S. (1998). Initial Conditions and Moment Restrictions in Dynamic Panel Data models. Journal of Econometrics, 87, 115-143.

Bolton, P., Scharfstein, D. (1990). A Theory of Predation Based on Agency Problems in Financial Contracting. American Economic Review, 80, 94-106. 
Brambor, T., Clark, W.R., Golder, M. (2006). Understanding Interaction Models: Improving Empirical Analyses. Political Analysis, 14, 63-82.

Bris, A., Welch, I., Zhu, N. (2006). The costs of bankruptcy: Chapter 7 liquidation versus Chapter 11 reorganization. The Journal of Finance, 59, 1253-1303.

Caselli, F., Esquivel, G., Lefort, F. (1996). Reopening the Convergence Debate: A New Look at CrossCountry Growth Empirics. Journal of Economic Growth, 1(3), 363-389.

Citron, D., Wright, M., Ball, R., Rippington, F. (2003). Secured creditor recovery from management buyouts in distress. European Financial Management, 9, 141-161.

Claessens, S., Klapper, L.F. (2005). Bankruptcy Around the World. Explanations of its Relative Use. American Law and Economics Review, 7, 253-283.

Couwenberg, O., de Jong, A. (2008). Costs and recovery rates in the Dutch liquidation-based bankruptcy system. European Journal of Law and Economics, 26(2), 105-127.

Couwenberg, O. (2001). Survival rates in bankruptcy systems: Overlooking the evidence. European Journal of Law and Economics, 12, 253-273.

Davydenko, S.A., Franks, J.R. (2005). Do bankruptcy codes matter? A study of defaults in France, Germany and the UK. ECGI Finance Working paper no. 89.

Dewatripont, M., Tirole, J. (1994). A Theory of Debt and Equity: Diversity of Securities and ManagerShareholder Congruence. Quarterly Journal of Economics, 109, 1027-54.

Djankov, S., Glaeser, E., La Porta, R., Lopez-de-Silanes, F., Shleifer, A. (2003). The New Comparative Economics. Journal of Comparative Economics, 31, 595-619.

Djankov, S., Hart, O., McLiesh, C., Shleifer, A. (2007). Debt Enforcement Around the World. ECGI Finance Working Paper no. 147.

European Commission (2008), Towards a Common Operational European Definition of Over-Indebtedness. Directorate General for Employment, Social Affair and Equal Opportunities.

Ferris, S.P., Lawless, R.M. (2000). The expenses of financial distress: The direct costs of Chapter 11. University of Pittsburgh Law Review, 61, 629-669.

Franks, J.R., Sussman, O. (2005). Financial distress and bank restructuring of small to medium sized UK componies. Review of Finance, 9, 65-96.

Franks, J.R., Nyborg, K.G., Torous, W.N. (1996). A comparison of US, UK, and German insolvency codes. Financial Management, 25, 86-101.

Franks, J.R., Torous, W.N (1994). A comparison of financial recontracting in distressed exchanges and Chapter 11 reorganizations. Journal of Financial Economics, 35, 349-370.

Franzoni, L.A., Marchesi, D. (2006). Economia e politica economica del diritto. Bologna: il Mulino.

Gennaioli, N., Rossi, S. (2006). Bankruptcy Litigation and Debt Contracts. Stockholm School of economics: Mimeo.

Hart, O. (1995). Firms, Contracts and Financial Structure. Oxford University Press.

Hart, O., Moore, J. (1989). Default and Renegotiation: A Dynamic Model of Debt. MIT Working Paper no.520.

Hart, O., La Porta, R., Lopez-de-Silanes, F., Moore, J. (1997). A new bankruptcy procedure that uses multiple auctions. NBER Working Paper Series no.6278.

Islam, N. (1995). Growth empirics: a panel data approach. The Quarterly Journal of Economics, 110(4), 1127-1170.

King, R.G., Levine, R. (1993). Finance and Growth: Schumpeter might be right. Quarterly Journal of Economics, 108, 717-737.

La Porta, R., Lopez-de-Silanes, F., Shleifer, A., Vishny, R. (1998). Law and Finance. Journal of Political Economy, 106(6), 1113-1155.

La Porta, R., Lopez-de-Silanes, F., Shleifer, A., Vishny, R. (1997). Legal Determinants of External Finance. Journal of Finance, 52(3), 1131-50.

Levine, R. (1998). The Legal Environment, Banks, and the Long-Run Economic Growth. Journal of Money, Credit and Banking, 30(3), Part 2: Comparative Financial Systems, 596-613.

Levine, R., Zervos, S. (1998). Stock Markets, Banks and Economic Growth. American Economic Review, 88, 537-558.

Lopucki, L.M., Doherty, J.W. (2004). The determinants of professional fees in large bankruptcy reorganization cases. Journal of Empirical Legal Studies, 1, 111-141. 
Lubben, S.J. (2000). The direct costs of corporate reorganization: An empirical examination of professional fees in large Chapter 11 cases. American Bankruptcy Journal ,74, 509-551.

Rajan, R.G., Zingales, L. (1998). Financial Dependence and Growth. American Economic Review, 88, 559586.

Ravid, S.A., Sundgren, S. (1998). The comparative efficiency of small-firm bankruptcies: A study of the US and the Finnish bankruptcy codes. Financial Management, 27, 28-40.

Roodman, D. (2006). How to Do xtabond2: An Introduction to "Difference" and "System" GMM in Stata. Center for Global Development, Working Paper no. 103.

Stanghellini, L. (2007). Le crisi di impresa fra diritto ed economia. Le procedure di insolvenza. Bologna: il Mulino.

Sundgren, S. (1998). Does a reorganization law improve the efficiency of the insolvency law? The Finnish experience. European Journal of Law and Economics, 6, 177-198.

Tashijan, E., Lease, R.C., McConnell, J.J. (1996). Prepacks, an empirical analysis of prepackaged bankruptcies. Journal of Financial Economics, 40, 135-162.

The Economist (2002). Fixing failed firms should be based on economics, not revenge”, Jan 8th.

Thorburn, K.S. (2000). Bankruptcy auctions: Costs, debt recovery, and firm survival. Journal of Financial Economics, 58, 337-368.

Tirole, J. (2006). The Theory of Corporate Finance. Princeton University Press.

Trew, A.W. (2006). Finance and Growth: A Critical Survey. Centre for Dynamic Macroeconomic Analysis. Working Paper Series, no. 0507.

Weiss, L.A. (1990). Bankruptcy resolution, direct costs and violation of priority of claims. Journal of Financial Economics, 27, 285-314.

Wooldridge, J.M.(2002). Econometric Analysis of Cross Section and Panel Data. London: MIT Press.

World Bank, Doing Business, 2004-2008, in www.doingbusiness.org.

World Bank (2008), World Development Report.

Zwiebel, J. (1996). Dynamic capital structure under managerial entrenchment. American Economic Review, 86, 1197-1215. 


\section{APPENDIX}

Table A1 Selected Countries

\begin{tabular}{|c|c|c|c|}
\hline Algeria & Estonia & Macedonia, FYR & Sierra Leone \\
\hline Angola & Finland & Malawi & Singapore \\
\hline Argentina & France & Malaysia & Slovakia \\
\hline Armenia & Georgia & Mexico & Slovenia \\
\hline Australia & Germany & Moldova & South Africa \\
\hline Austria & Greece & Morocco & Spain \\
\hline Belarus & Guatemala & Mozambique & Sri Lanka \\
\hline Belgium & Honduras & Namibia & Sweden \\
\hline Botswana & Hong Kong, China & Netherlands & Switzerland \\
\hline Brazil & Hungary & New Zealand & Syria \\
\hline Bulgaria & Indonesia & Nicaragua & Tanzania \\
\hline Canada & Ireland & Nigeria & Thailand \\
\hline Chile & Israel & Norway & Togo \\
\hline China & Italy & Oman & Ukraine \\
\hline Colombia & Jamaica & Panama & United Kingdom \\
\hline Costa Rica & Japan & Papua New Guinea & United States \\
\hline Croatia & Jordan & Paraguay & Uruguay \\
\hline Czech Republic & Kazakhstan & Peru & Venezuela \\
\hline Denmark & Korea & Philippines & Vietnam \\
\hline Dominican Republic & Kuwait & Poland & Yemen \\
\hline Ecuador & Latvia & Portugal & Zambia \\
\hline Egypt & Lebanon & Romania & Zimbabwe \\
\hline El Salvador & Lithuania & Russia & \\
\hline
\end{tabular}

Table A2 Data and Sources

\begin{tabular}{|c|c|}
\hline & Sources \\
\hline \multirow{2}{*}{$\begin{array}{l}\text { Investment Share of real } \\
\text { GDP }\end{array}$} & Penn World Table 6.2 \\
\hline & International Financial Statistics, International Monetary Fund \\
\hline \multirow{5}{*}{ Bankruptcy Law } & World Bank, Doing Business Report (several issues) \\
\hline & Djankov, S., Hart, O., McLiesh, C., Shleifer, A. (2007). Debt \\
\hline & Enforcement Around the World. ECGI Finance Working Paper no. 147. \\
\hline & Couwenberg, O. (2001). Survival rates in bankruptcy systems: \\
\hline & $\begin{array}{l}\text { Overlooking the evidence. European Journal of Law and Economics, } \\
12,253-273 \text {. }\end{array}$ \\
\hline $\begin{array}{l}\text { Closing a Business: } \\
\text { Enforcement Rank }\end{array}$ & World Bank, Doing Business Report (several issues) \\
\hline \multirow{2}{*}{ Rule of Law } & The Worldwide Governance Indicators (WGI) project (several issues) \\
\hline & World Bank: http://info.worldbank.org/governance/wgi2008/ \\
\hline Interest rate & International Financial Statistics, International Monetary Fund \\
\hline (lending rate) & $\begin{array}{l}\text { OECD Economic Outlook No 81: Annual and Quarterly data } \\
\text { World Bank, World Development Report (Selected Indicators) (several }\end{array}$ \\
\hline Gross National Savings & $\begin{array}{l}\text { issues) } \\
\end{array}$ \\
\hline Financial Development & $\begin{array}{l}\text { World Bank, World Development Report (Selected Indicators) (several } \\
\text { issues) }\end{array}$ \\
\hline $\begin{array}{l}\text { Composite rate } \\
\text { (Investment Profile) }\end{array}$ & $\begin{array}{l}\text { International Country Risk Guide } \\
\text { (PRS Group) }\end{array}$ \\
\hline
\end{tabular}


Table A3 Summary Statistics

\begin{tabular}{|l|ccccc|}
\hline \multicolumn{1}{|c|}{ Variable } & Mean & $\begin{array}{c}\text { Standard } \\
\text { Deviation }\end{array}$ & $\begin{array}{c}\text { Relative } \\
\text { Standard } \\
\text { Deviation } \sigma_{r}\end{array}$ & Min & Max \\
\hline Investment/GDP & 15.94 & 7.74 & 0.48 & 2.01 & 42.53 \\
Interest Rate (Lending) & 23.81 & 25.70 & 1.07 & 1.81 & 207 \\
Gross National Savings & 18.46 & 12.24 & 0.66 & -29 & 53 \\
Rule of Law & 55.46 & 28.57 & 0.51 & 2.4 & 100 \\
Investment Risk & 9.42 & 2.29 & 0.24 & 0.7 & 12.5 \\
Financial Market & 64.60 & 52.25 & 0.80 & -78 & 312.5 \\
Development & & & & & \\
Bankruptcy & 67.27 & 44.96 & 0.66 & 1 & 151 \\
Enforcement (ranking) & & & & & \\
time & 2.87 & 1.58 & 0.55 & 0.4 & 10 \\
cost & 13.89 & 9.49 & 0.68 & 1 & 42 \\
recovery rate & 40.55 & 25.90 & 0.63 & 0 & 94 \\
Bankruptcy Law & 1.81 & 1.06 & 0.58 & 0 & 3 \\
Dummy Poor/Rich & 0.60 & 0.48 & 0.8 & 0 & 1 \\
Countries & & & & & \\
\hline
\end{tabular}

Table A4 The multiplicative interaction model with all constitutive terms

\begin{tabular}{|c|c|c|c|c|c|c|}
\hline $\begin{array}{l}\text { Dependent } \\
\text { Variable: }\end{array}$ & $\begin{array}{l}\text { Pooled } \\
\text { OLS }\end{array}$ & & $\begin{array}{c}\text { Random } \\
\text { Effects }\end{array}$ & & Fixed Effect & \\
\hline INV/GDP & $\begin{array}{c}\text { Rich } \\
\text { (1) }\end{array}$ & $\begin{array}{c}\text { Poor } \\
(2)\end{array}$ & $\begin{array}{c}\text { Rich } \\
\text { (3) }\end{array}$ & $\begin{array}{c}\text { Poor } \\
(4)\end{array}$ & $\begin{array}{c}\text { Rich } \\
\text { (5) }\end{array}$ & $\begin{array}{c}\text { Poor } \\
(6)\end{array}$ \\
\hline Bankruptcy Law & $\begin{array}{l}-0.001 \\
(0.002)\end{array}$ & $\begin{array}{l}0.0004 \\
(0.008)\end{array}$ & $\begin{array}{l}-0.008 \\
(0.005)\end{array}$ & $\begin{array}{l}-0.005 \\
(0.005)\end{array}$ & $\begin{array}{l}-0.001 \\
(0.004)\end{array}$ & $\begin{array}{c}0.06 \\
(0.003)\end{array}$ \\
\hline $\begin{array}{l}\text { Bankruptcy } \\
\text { Enforcement } \\
\text { (ranking) }\end{array}$ & $(0.001)$ & -0.002 & $-0.005^{*}$ & $-0.005^{*}$ & -0.008 & $(0.0012)$ \\
\hline Interaction & $\begin{array}{c}-0.00 \\
(0.000)\end{array}$ & $\begin{array}{c}0.00 \\
(0.000)\end{array}$ & $\begin{array}{c}0.001 \\
(0.001)\end{array}$ & $\begin{array}{c}0.001 \\
(0.001)\end{array}$ & $\begin{array}{l}0.003 \\
(0.09)\end{array}$ & $\begin{array}{c}0.01 \\
(0.006)\end{array}$ \\
\hline Interest rate & $\begin{array}{l}-0.06 * \\
(0.035)\end{array}$ & $\begin{array}{l}0.15^{* *} \\
(0.058)\end{array}$ & $\begin{array}{c}-0.20 * * * \\
(0.031)\end{array}$ & $\begin{array}{c}-0.002 \\
(0.060)\end{array}$ & $\begin{array}{c}-0.22 * * * \\
(0.034)\end{array}$ & $\begin{array}{c}-0.06 \\
(0.067)\end{array}$ \\
\hline $\begin{array}{l}\text { Gross National } \\
\text { Savings }\end{array}$ & $\begin{array}{l}0.15^{* * *} \\
(0.048)\end{array}$ & $\begin{array}{l}0.09 * * \\
(0.044)\end{array}$ & $\begin{array}{l}0.09 * * \\
(0.043)\end{array}$ & $\begin{array}{l}0.005 \\
(0.043)\end{array}$ & $\begin{array}{l}0.10 * * \\
(0.047)\end{array}$ & $\begin{array}{c}-0.01 \\
(0.047)\end{array}$ \\
\hline Rule of Law & $\begin{array}{c}0.11^{*} \\
(0.064)\end{array}$ & $\begin{array}{l}0.15^{* *} \\
(0.061)\end{array}$ & $\begin{array}{c}0.13^{*} \\
(0.072)\end{array}$ & $\begin{array}{c}0.11^{*} \\
(0.060)\end{array}$ & $\begin{array}{c}0.25^{* * *} \\
(0.094)\end{array}$ & $\begin{array}{c}0.06 \\
(0.070)\end{array}$ \\
\hline Investment Risk & $\begin{array}{c}-0.44 * * * \\
(0.116)\end{array}$ & $\begin{array}{l}-0.14^{* *} \\
(0.071)\end{array}$ & $\begin{array}{c}-0.33^{* *} \\
(0.175)\end{array}$ & $\begin{array}{l}-0.29 * \\
(0.155)\end{array}$ & $\begin{array}{c}0.69 \\
(0.433)\end{array}$ & $\begin{array}{c}-0.46 \\
(0.377)\end{array}$ \\
\hline
\end{tabular}




\begin{tabular}{|c|c|c|c|c|c|c|}
\hline $\begin{array}{l}\text { Financial } \\
\text { Development }\end{array}$ & $\begin{array}{c}0.20 * * * \\
(0.041)\end{array}$ & $\begin{array}{c}0.18^{* * *} \\
(0.057)\end{array}$ & $\begin{array}{c}0.11^{* * *} \\
(0.037)\end{array}$ & $\begin{array}{c}0.14 * * * \\
(0.046)\end{array}$ & $\begin{array}{l}0.09 * * \\
(0.044)\end{array}$ & $\begin{array}{l}0.11^{* *} \\
(0.056)\end{array}$ \\
\hline Constant & $\begin{array}{l}2.5^{* * *} \\
(0.346)\end{array}$ & $\begin{array}{c}0.78 \\
(0.522)\end{array}$ & $\begin{array}{c}3.21 * * * \\
(0.534)\end{array}$ & $\begin{array}{c}2.43 * * * \\
(0.68)\end{array}$ & $\begin{array}{c}0.57 \\
(1.29)\end{array}$ & $\begin{array}{c}4.16 \\
(1.24)\end{array}$ \\
\hline R-squared & 0.52 & 0.35 & 0.49 & 0.29 & 0.32 & 0.20 \\
\hline F test & $53.24 * * *$ & $9.15^{* * *}$ & $131.34 * * *$ & $36.63 * * *$ & $6.87 * * *$ & \\
\hline $\begin{array}{l}\text { Country Effects } \\
\text { (F test) }\end{array}$ & & & & & $13.38 * * *$ & $10.19 * * *$ \\
\hline $\begin{array}{l}\text { Time Effects (F } \\
\text { test) }\end{array}$ & & & $19.01 * * *$ & & $5.04 * * *$ & 0.92 \\
\hline $\begin{array}{l}\text { Breusch-Pagan } \\
\text { Test }\end{array}$ & & & $231.79 * * *$ & $115.62 * * *$ & & \\
\hline Hausman Test & & & $22.02 * *$ & 10.90 & & \\
\hline Observations & 264 & 149 & 264 & 149 & 263 & 149 \\
\hline
\end{tabular}

Standard errors in parenthesis

*, **, ***, for $10 \%, 5 \%$ and $1 \%$ significance level respectively 